\title{
Studies on Retail Chicken Meats With A Special Reference to Antibiotic Resistant Bacteria
}

Elabbasy, M. T. and Morshdy, A. M.

Food Control Dept., Faculty of Vet. Med., Zagazig University, Egypt.

\begin{abstract}
This study was conducted on retail chicken meats to determine the prevalence of antibiotic resistant bacteria.The prevalence of antibiotic resistant bacteria in retail chicken meat was determined in hail region, Saudi Arabia. A total of 50 samples were collected and examined for the presence of antibiotic resistant bacteria. $E$. coli was the most prevalent isolates (48\%) followed by $S$. aureus $(24 \%)$ and Salmonella (20\%). Some of them were multi-drug resistant (MDR). Resistance of S. aureus, E. coli and Salmonella spp. to tetracycline was most frequent at $25 \%, 79.16 \%$ and $60 \%$, respectively. These findings suggest that the abundant presence of multi-drug resistant bacteria in the chicken meat may have a profound effect on future treatment options for a wide range of infections caused by bacteria.
\end{abstract}

Key words: chicken meats, Antimicrobial resistant; MDR; $E$. coli; Salmonella and S. aureus.

\section{Introduction}

Chicken meat can make numerous positive commitments to the eating routine of those on low livelihoods. Despite not all meats are seen Likewise healthy, chicken meat is cheap now and again more moderate than different meats. It can be advanced with some key supplements around the world as it is of a consistently high quality, is low in saturated fats.

There has been expanding worry on the rise of multidrug-resistant foodborne pathogens from food, including poultry (Kilonzo-Nthenge et al., 2013). contamination of food with antibiotic-resistant foodborne pathogens continues to be a major risk to public health and potentially compromises the treatment of severe bacterial infections (Van et al., 2007). The resistance of bacteria to antimicrobials will continue to threaten the therapeutic use of antibiotics in clinical medicine if massive use of antibiotics is not restricted (McGowan Jr, 2001). Antimicrobials are used to improve animal growth and disease control (Tollefson and Miller, 2000). the used antibiotics in treatment of animal and human are mostly the same consequently expanding the danger of development and spread of resistant bacteria in both animals and humans (W.H.O., 2007). Tetracyclines, aminoglycosides, $\beta$ - 
lactams, lincosamides, macrolides, and sulfonamides were broadly utilized in poultry and animal farms (Lee et al., 2001).

Antibiotics are used to control the susceptible bacterial infection, at a therapeutic dose, while strains with unusual traits can be developed and can multiply and exhibit resistance to antibiotics (Apata, 2012). Some of the antimicrobial resistant genes detected in isolated bactreia from food also identified in humans due to consumption of food containing resistant bacteria or through contact and this accentuate the indirect transfer by food handling and/or consumption (Marshall and Levy, 2011). So the purpose of this study was to determine the prevalence of drug-resistant bacteria in chicken meat.

\section{Materials and methods \\ Samples collection preparation:}

Fifty whole chicken carcasses samples were purchased from different groceries in Hail region, Saudi Arabia. Twenty five grams of each sample were homogenized in $225 \mathrm{ml}$ of buffered peptone water (BPW), under aseptic conditions for 2 min. by using a sterile homogenizer.

Isolation and Identification of bacteria:

Isolation of the foodborne pathogens E. coli, Salmonella and $S$. aureus and K. pneumoniae were carried out according to (BAM et al., 1998). Identification of bacterial strains was performed by using conventional methods including catalase, coagulase and mannitol fermentation tests, and Gramstaining. Further the identification was confirmed by MALDI-TOF and Microscan, according to the manufacturer's guidelines of (van Veen et al., 2010). A single colony of a (sub) culture was directly deposited in duplicate on a MALDITOF-MS plate (Bruker Daltonik $\mathrm{GmbH}$, Germany) and the results were recorded

Susceptibility testing of isolated bacteria:

Isolates were tested for susceptibility to antimicrobials by Microscan method [susceptibility based on minimum inhibitory concentration (MIC)].The isolates were also tested for their antimicrobial susceptibilities by the disc diffusion technique using the following antibiotic discs for Gram positives: amoxicillin $(30 \mu \mathrm{g})$, ampicillin $(10 \mu \mathrm{g})$, cefepime (30 $\mu \mathrm{g})$, cefotaxime $(30 \mu \mathrm{g})$, cefuroxime (30 $\mu \mathrm{g})$, cephalexin $(30 \mu \mathrm{g})$, chloramphenicol $\quad(30 \mu \mathrm{g})$, ciprofloxacin $(5 \mu \mathrm{g})$, clindamycin $(2$ $\mu \mathrm{g})$, erythromycin $(15 \mu \mathrm{g})$, gentamicin $(10 \mu \mathrm{g})$, methicillin $(5$ $\mu \mathrm{g})$, oxacillin $(1 \mu \mathrm{g})$, rifampicin $(5$ $\mu \mathrm{g})$, roxithromycin (15 $\mu \mathrm{g})$, streptomycin $(10 \mu \mathrm{g})$, trimethoprimsulfamethoxazole $(5 \mu \mathrm{g})$ and vancomycin $(30 \mu \mathrm{g})$. For Gram negatives the antimicrobials tested will be as follows, ampicillin (10 $\mu \mathrm{g})$, cotrimoxazole $(25 \mu \mathrm{g})$, 
chloramphenicol $\quad(30 \quad \mu \mathrm{g})$, ciprofloxacin $(5 \mu \mathrm{g})$, ceftazidime (30 $\mu \mathrm{g})$, ceftriaxone $(30 \mu \mathrm{g})$, nalidixic acid $(10 \mu \mathrm{g})$, meropenem $(10 \mu \mathrm{g})$, tigecycline $(15 \mu \mathrm{g})$, colistin $(10 \mu \mathrm{g})$ and polymixin (300 units). MIC values were determined following (Watts et al., 2008) interpretative standards.

\section{Results and Discussion}

The standard treatment of infections can be affected due to resistant bacteria resulting in bad prognosis and a greater risk of death. Antimicrobial-resistant bacteria in animals are a growing concern because of their potential for transmission to humans as foodborne pathogens (Welton et al., 1998; Witte, 1998). Antibiotic resistant bacteria and resistance genes can be evolved and transferred to people through the consumption of meat or even through direct contact with food animals which in turn threaten the effective prevention and treatment of bacterial infections (Darwish et al., 2013). The emergence of antibiotic resistance can increase the difficulties of human treatment and this might be increased by the indiscriminate use of antibiotics in poultry and animal farm., so it is better to use some classes of antibiotics for animal diseases treatment and other classes for human treatment (Darwish et al., 2013)

The incidences of bacteria found in chicken meat are shown in figure 1.
E. coli was the most frequent bacterial contaminant by $48 \%$ followed $S$. aureus (24\%), Salmonella (20\%) and $K$. pneumoniae $(16 \%)$. Although most strains of E. coli are not regarded as pathogens, they can be opportunistic pathogens that cause infections in immunocompromised hosts and there are also pathogenic strains of E. coli that when ingested, causes gastrointestinal illness in healthy humans (BAM et al., 1998). Drug-resistant strains of $E$. coli isolated from humans are originated from meat and meat products; these strains are highly resistant to fluoroquinolones and can spread into the community from food chains (Collignon, 2009).

Salmonella is an important cause of food-borne illness and the development of resistant strains is associated with the extra use of antibiotics in animals; and can be transmitted to humans (White et al., 2001). Multidrug resistance was detected in $92.8 \%$ of the isolated Salmonella Which confirms the contamination of chicken meat with multidrug-resistant strains representing a danger to public health (Abd-Elghany et al., 2015).

$S$. aureus is a leading cause of food poisoning and many infections to human such as pneumonia and postoperative wound infections (de Boer et al., 2009; Horan et al., 1988). The presence of Methicillinresistant

Staphylococcus aureus (MRSA) in raw meat may constitute a health hazard to 
consumers (KITAI et al., 2005).

Recently, methicillinresistant Staphylococcus

aureus (MRSA) strains could be isolated from several foodproducing animals (de Boer et al., 2009; KITAI et al., 2005; Lee, 2003). Further studies are expected to explain the transmission courses of MRSA in connection to meat and other foods and to give the abilities to ban the spread of MRSA. The emergence of MRSA in human infection significantly related to the high prevalence of MRSA in meat which consider a greater health hazard for consumers (de Boer et al., 2009). K. pneumoniae is responsible for infections of immunocompromised patients as it is an opportunistic pathogens associated with $2 \%-5 \%$ of nosocomial infections especially the urinary and respiratory tracts (Podschun and Ullmann, 1998). In the study of (Calbo et al., 2011) who reported the transmission of ESBL- $K$. pneumoniae through the food where food can be a transmission vector for multidrugresistant strains in the hospital setting, and they should consider extending their surveillance to kitchen facilities and foodstuff. Another study reported $K$. pneumoniae as an enteroinvasive food-borne pathogen transmitted from a hamburger (Sabota et al., 1998).

Contamination of chicken meat with antibiotic resistant bacteria was identified and represented in table 1 . The level of resistance was high and many bacteria were resistant to more than one antibiotic. Results indicate that isolated $E$. coli was resistant to amoxicillin clavulanate, ampicillin, gentamicin, tetracycline, moxifolxacin and trimethoprim/sulfamethoxazole while Salmonella spp. were resistant to amoxicillin clavulanate, ampicillin, tetracycline, moxifolxacin and trimethoprim/sulfamethoxazole. $S$. aureus isolates were resistant to ciprofloxacin, tetracycline, moxifolxacin, cefoxitin, amikacin, trimethoprim /sulfamethoxazole. The antimicrobial susceptibility pattern of the $K$. pneumoniae showed a resistance to amoxicillin Clavulanate, ampicillin, tetracycline, vancomycin, cefoxitin and amikacin.

A bacterial resistance to multiple antimicrobials is adding to the problem of meat contamination from animal hides, feces, environments (Graham et al., 2009). The highest MDR was observed for E. coli $(91.6 \%)$ followed by $S$. aureus $(75 \%)$. Many studies in the Saudi Arabia reported the occurrence of antimicrobial resistant bacteria isolated from chicken mean (Altalhi et al., 2010; Greeson et al., 2013)

Although at least some of these bacteria may not be pathogenic strains themselves, they are a cause of concern because they can extend 
antibiotic resistance to other bacteria (Greeson et al., 2013).

Antibiotic resistant, but not susceptible from human infections in the United States were found to be indistinguishable from those in chickens suggesting a directional transmission of resistant bacteria from a food source (Weese et al., 2010). Many studies reported the emergence of many antimicrobialresistant E. coli strains which were responsible for infections of the urinary tract and bloodstream in humans and originated from contaminated retail meat (Carlet et al., 2012).
The obtained results reported the presence of antibiotic resistant bacteria isolated from chicken meat which may have a serious consequences for public health and can affect consumers. The occurrence of resistant bacteria could be attributed to the indiscriminate use of antibiotics in poultry farms. Data are lacking link between the uses of antibiotics in animals and the development of multiple drug resistant bacteria so the scientific community has been forced to follow and research for the reservoir of resistant microorganisms.

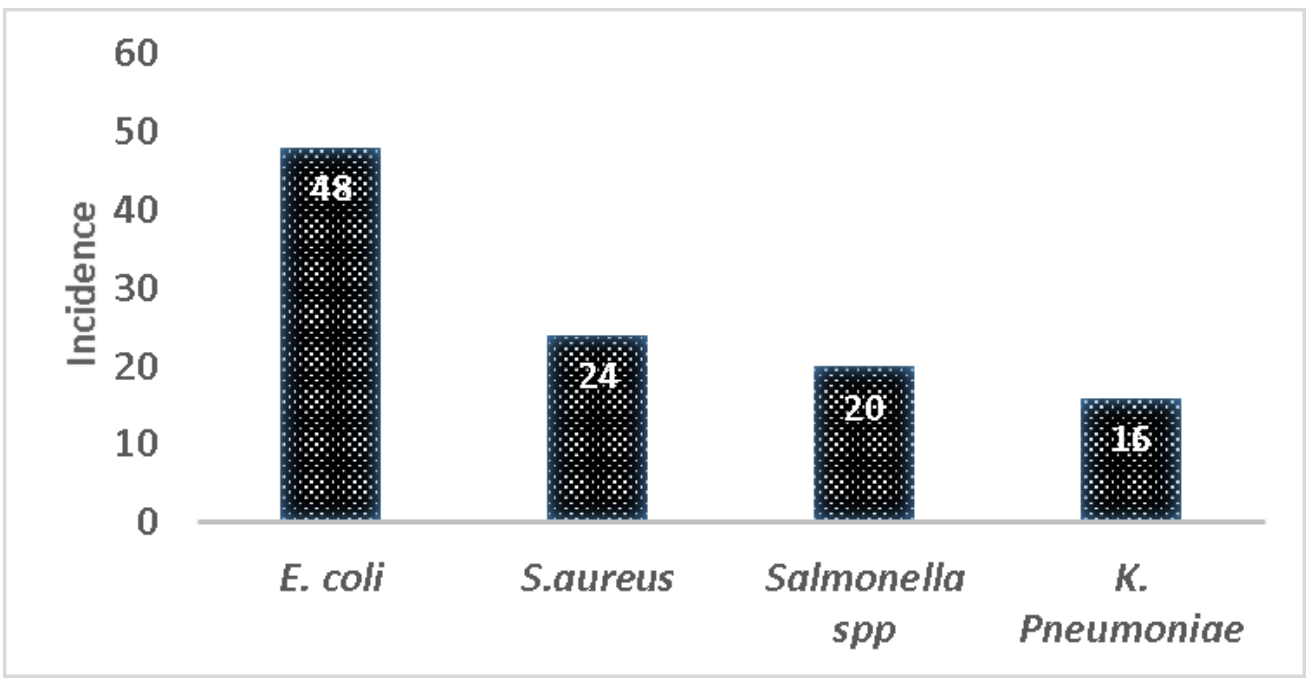

Figure 1. Incidence of some bacteria in examined chicken meat samples $(n=50)$.

E. coli $=$ Escherichia coli

S. aureus $=$ Staphylococcus aureus

K. pneumoniae $=$ Klebsiella pneumonia 
Table 1. Prevalence of drug-resistant bacteria isolated from raw chicken meat

\begin{tabular}{|c|c|c|c|c|}
\hline Antibiotic & $\begin{array}{c}\text { S. aureus } \\
\mathrm{n}=12\end{array}$ & $\begin{array}{c}\text { K. } \\
\text { pneumoniae } \\
\mathrm{n}=8\end{array}$ & $\begin{array}{c}\text { E. coli } \\
\mathrm{n}=24\end{array}$ & $\begin{array}{c}\text { Salmonella } \\
\mathrm{spp} \\
\mathrm{n}=10 .\end{array}$ \\
\hline MDR* & $9(75 \%)$ & $2(25 \%)$ & $22(91.6 \%)$ & $5(50 \%)$ \\
\hline Amoxicillin clavulanate & $0(0)$ & $4(50 \%)$ & $1(4.16 \%)$ & $1(10 \%)$ \\
\hline Ampicillin & $0(0)$ & $1(12.5 \%)$ & $15(62.5 \%)$ & $2(20 \%)$ \\
\hline Ciprofloxacin & $1(8.3 \%)$ & $0(0)$ & $0(0)$ & $0(0)$ \\
\hline Gentamicin & $0(0)$ & $0(0)$ & $3(12.5 \%)$ & $0(0)$ \\
\hline Tetracycline & $3(25 \%)$ & $6(75 \%)$ & $19(79.16 \%)$ & $6(60 \%)$ \\
\hline Vancomycin & $0(0)$ & $1(12.5 \%)$ & $0(0)$ & $0(0)$ \\
\hline Moxifolxacin & $1(8.3 \%)$ & $0(0)$ & $6(25 \%)$ & $30(30 \%)$ \\
\hline Cefoxitin & $1(8.3 \%)$ & $2(25 \%)$ & $0(0)$ & $0(0)$ \\
\hline Amikacin & $1(8.3 \%)$ & $1(12.5 \%)$ & $0(0)$ & $0(0)$ \\
\hline Trimethoprim/sulfamethoxazole & $1(8.3 \%)$ & $0(0)$ & $2(8.3 \%)$ & $4(40 \%)$ \\
\hline
\end{tabular}

*MDR Multi-drug resistant

\section{References}

Abd-Elghany, S., Sallam, K., Abd-Elkhalek, A., Tamura, T. (2015): Occurrence, genetic characterization and antimicrobial resistance of Salmonella isolated from chicken meat and giblets. Epidemiology and infection 143, 997-1003.

Altalhi, A.D., Gherbawy, Y.A., Hassan, S.A. (2010): Antibiotic resistance in Escherichia coli isolated from retail raw chicken meat in Taif, Saudi Arabia. Foodborne pathogens and disease 7, 281-285.

Apata, D. (2012): The emergence of antibiotics resistance and utilization of probiotics for poultry production. Science Journal of Microbiology 2012.
BAM, F., Hunt, J., Abeyta, C., Tran, T., 1998. FDA Bacteriological Analytical Manual. Chapter 7, 23.

Calbo, E., Freixas, N., Xercavins, M., Riera, M., Nicolás, C., Monistrol, O., del mar Solé, M., Sala, M.R., Vila, J., Garau, J. (2011): Foodborne nosocomial outbreak of SHV1 and CTX-M-15producing Klebsiella pneumoniae: epidemiology and control. Clinical Infectious Diseases 52, 743-749.

Carlet, J., Jarlier, V., Harbarth, S., Voss, A., Goossens, H., Pittet, D. (2012): Ready for a world without antibiotics? The pensières antibiotic resistance call to action. Antimicrobial resistance and infection control 1, 1-13. 
Collignon, P. (2009): Resistant Escherichia coli-we are what we eat. Clinical infectious diseases 49, 202-204.

Darwish, W.S., Eldaly, E.A., ElAbbasy, M.T., Ikenaka, Y., Nakayama, S., Ishizuka, M. (2013): Antibiotic residues in food: the African scenario. Japanese Journal of Veterinary Research 61, S13-S22.

de Boer, E., Zwartkruis-Nahuis, J.T.M., Wit, B., Huijsdens, X.W., de Neeling, A.J., Bosch, T., van Oosterom, R.A.A., Vila, A., Heuvelink, A.E. (2009): Prevalence of methicillin-resistant Staphylococcus aureus in meat. International Journal of Food Microbiology 134, 52-56.

Graham, J.P., Price, L.B., Evans, S.L., Graczyk, T.K., Silbergeld, E.K. (2009): Antibiotic resistant enterococci and staphylococci isolated from flies collected near confined poultry feeding operations. Science of the total environment 407, 2701-2710.

Greeson, K., Suliman, G.M., Sami, A., Alowaimer, A., Koohmaraie, M. (2013): Frequency of antibiotic resistant Salmonella, Escherichia coli, Enterococcus, and Staphylococcus aureus in meat in Saudi Arabia. African Journal of Microbiology Research 7, 309-316.

Horan, T., Culver, D., Jarvis, W., Emori, G., Banerjee, S., Martone, W., Thornsberry, C. (1988): Pathogens causing nosocomial infections preliminary data from the national nosocomial infections surveillance system. Antimicrobic Newsletter 5, 65-67.

Kilonzo-Nthenge, A., Rotich, E., Nahashon, S. (2013): Evaluation of drug-resistant Enterobacteriaceae in retail poultry and beef. Poultry science 92, 1098-1107.

KITAI, S., Shimizu, A., KAWANO, J., Sato, E., Nakano, C., Uji, T., Kitagawa, H. (2005): Characterization of methicillinresistant Staphylococcus aureus isolated from retail raw chicken meat in Japan. Journal of veterinary medical science $67,107-110$.

Lee, J.H. (2003): Methicillin (oxacillin)-resistant Staphylococcus aureus strains isolated from major food animals and their potential transmission to humans. Applied and Environmental Microbiology 69, 6489-6494.

Lee, M., Lee, H., Ryu, P. (2001): Public health risks: Chemical and antibiotic residues-review. AsianAustralasian Journal of Animal Sciences 14, 402-413.

Marshall, B.M., Levy, S.B. (2011): Food animals and antimicrobials: impacts on human health. Clinical microbiology reviews 24, 718-733. McGowan Jr, J.E., 2001. Economic impact of antimicrobial resistance. Emerging infectious diseases 7, 286.

Organization, W.H. (2007): Critically important antimicrobials for human medicine: categorization for the development of risk management strategies to contain antimicrobial resistance due to non- 
human antimicrobial use: report of the second WHO Expert Meeting, Copenhagen, 29-31 May 2007.

Podschun, R., Ullmann, U. (1998): Klebsiella spp. as nosocomial pathogens: epidemiology, taxonomy, typing methods, and pathogenicity factors. Clinical microbiology reviews 11, 589-603.

Sabota, J.M., Hoppes, W.L., Ziegler, J.R., DuPont, H., Mathewson, J., Rutecki, G.W. (1998): A new variant of food poisoning: enteroinvasive Klebsiella pneumoniae and Escherichia coli sepsis from a contaminated hamburger. The American journal of gastroenterology 93, 118-119.

Tollefson, L., Miller, M.A. (2000): Antibiotic use in food animals: controlling the human health impact. Journal of AOAC international 83, 245-254.

Van, T.T.H., Moutafis, G., Istivan, T., Tran, L.T., Coloe, P.J. (2007): Detection of Salmonella spp. in retail raw food samples from Vietnam and characterization of their antibiotic resistance. Applied and environmental microbiology 73, 6885-6890.

van Veen, S.Q., Claas, E., Kuijper, E.J. (2010): Highthroughput identification of bacteria and yeast by matrix-assisted laser desorption ionization-time of flight mass spectrometry in conventional medical microbiology laboratories. Journal of clinical microbiology 48 , 900-907.

Watts, J.L., Clinical, Institute, L.S. (2008): Performance standards for antimicrobial disk and dilution susceptibility tests for bacteria isolated from animals: approved standard. National Committee for Clinical Laboratory Standards.

Weese, J.S., Reid-Smith, R., Rousseau, J., Avery, B. (2010): Methicillin-resistant

Staphylococcus aureus (MRSA) contamination of retail pork. The Canadian Veterinary Journal 51, 749.

Welton, L., Thal, L., Perri, M., Donabedian, S., McMahon, J., Chow, J., Zervos, M. (1998): Antimicrobial resistance in enterococci isolated from turkey flocks fed virginiamycin. Antimicrobial agents and chemotherapy 42, 705-708. White, D.G., Zhao, S., Sudler, R., Ayers, S., Friedman, S., Chen, S., McDermott, P.F., McDermott, S., Wagner, D.D., Meng, J. (2001): The isolation of antibiotic-resistant Salmonella from retail ground meats. New England journal of medicine 345, 1147-1154.

Witte, W. (1998): Medical consequences of antibiotic use in agriculture. Science 279, 996. 


\section{دراسات على لحوم الدواجن خاصة بالبكتريا المقاومة للمضادات الحيوية}

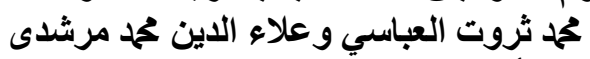

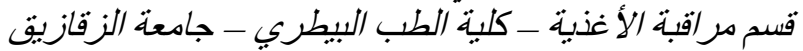

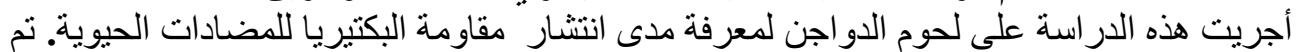

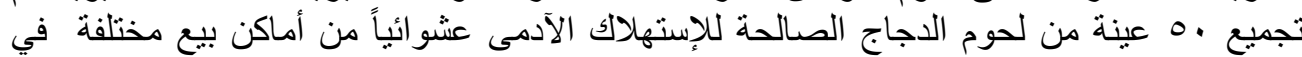

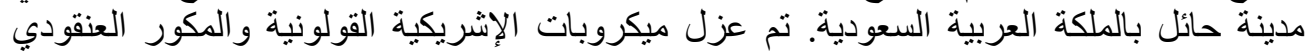

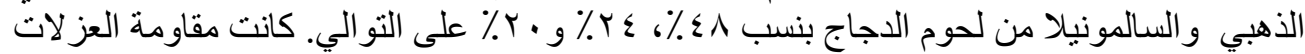

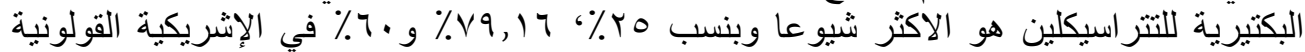

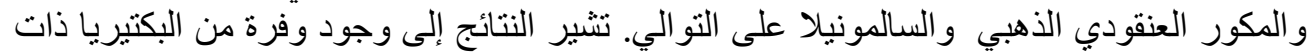

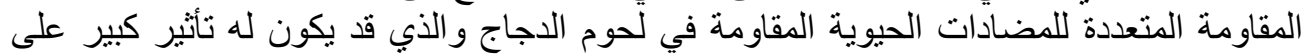

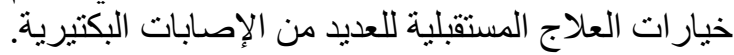

